\title{
DOES ULNA FIXATION ALTER THE OUTCOME FOR DISTAL- THIRD FOREARM FRACTURES IN CHILDREN?
}

\section{A FIXAÇÃO DA ULNA ALTERA O DESFECHO DAS FRATURAS DO TERÇO DISTAL DO ANTEBRAÇO?}

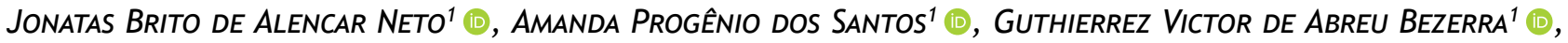 \\ luiz Holanda Pinto Neto ${ }^{1}$ (1), Maria luzete Costa Cavalcante ${ }^{2}$ (1)
}

1. Hospital do Instituto Dr. José Frota, Orthopedics and Traumatology Service, Fortaleza, Ceará, Brazil.

2. Universidade Federal do Ceará, Hospital Universitário Walter Cantídio, Department of Orthopedics, Fortaleza, Ceará, Brazil.

\begin{abstract}
Introduction: Fractures of the distal third of the forearm are common in the pediatric population. Conservative treatment of an ipsilateral fracture of the distal ulna metaphysis is one of the risk factors for loss of reduction. Percutaneous fixation of the fracture with K-wires is recommended. This study aims to evaluate the outcome of percutaneous fixation of both bones performed as the primary treatment. Materials and Methods: A randomized, open, prospective, clinical trial was conducted, including skeletally immature patients who underwent surgery for fractures of the distal radius and ulna. They were randomized into two groups, one with fixation only of the radius fracture and the other with fixation of both the radius and the ulna fractures, and they were followed clinically and radiologically for up to 12 weeks postoperatively. Results: Sixteen children were selected. In the intraoperative period, fluoroscopy was activated for a longer time when fixing the ulna $(p=0.011)$ and the surgical time was longer in this group $(p=0.014)$. In the postoperative evaluations, the group whose surgery involved the fixation of both bones had a lower postoperative pain score ( $p$ $<0.001)$ and less time away from school $(p<0.001)$. Conclusions: In this study, postoperative pain and absence from school were both less when fixation of the radius and ulna was performed. Evidence Level II; Randomized Controlled Study.
\end{abstract}

Keywords: Bone fractures. Forearm. Bone wires.

\section{RESUMO}

Introdução: As fraturas do terço distal do antebraço são comuns na população pediátrica. O tratamento conservador da fratura ipsilateral da metáfise distal da ulna é um dos fatores de risco para a perda da redução. Recomenda-se a fixação percutânea da fratura com fios K. Este estudo tem como objetivo avaliar o resultado da fixação percutânea de ambos os ossos realizada como tratamento primário. Materiais e Métodos: Foi realizado um estudo clínico randomizado, aberto e prospectivo, que incluiu pacientes com esqueleto imaturo que foram submetidos à cirurgia para fraturas da parte distal do rádio e a ulna. Os participantes foram randomizados em dois grupos, um com fixação apenas da fratura do rádio e outro com fixação das fraturas do rádio e da ulna, e foram acompanhados clínica e radiologicamente por até 12 semanas de pós-operatório. Resultados: Dezesseis crianças foram selecionadas. No intraoperatório, a fluoroscopia foi ativada por mais tempo na fixação da ulna ( $p=$ $0,011)$ e o tempo cirúrgico foi maior nesse grupo $(p=0,014)$. Nas avaliações pós-operatórias, o grupo cuja cirurgia envolveu a fixação de ambos os ossos teve escore de dor menor depois da cirurgia $(p<0,001)$ e menos tempo de afastamento da escola $(p<0,001)$. Conclusões: Neste estudo, a dor pós-operatória e o afastamento da escola foram menores quando se realizou fixação do rádio e da ulna. Nível de Evidência II; Estudo randomizado controlado.

Descritores: Fraturas ósseas. Antebraço. Fios ortopédicos.

Citation: Neto JBA, Santos AP, Bezerra GVA, Neto LHP, Cavalcante MLC. Does ulna fixation alter the outcome for distal-third forearm fractures in children? Acta Ortop Bras. [online]. 2022;30(1): Page 1 of 6 . Available from URL: http://www.scielo.br/aob.

\section{INTRODUCTION}

Fractures of the distal third of the forearm correspond to approximately $21 \%$ of all fractures in the pediatric population. ${ }^{1}$ Conservative treatment is the generally preferred in the long-term follow-up of children with metaphyseal fracture of the distal radius, consisting of closed reduction and immobilization with plaster. ${ }^{2}$ However, unacceptable displacement of reduction after this treatment method can occur in up to $39 \%$ of patients. ${ }^{3}$
Zamzam and Khoshhal observed that the initial displacement of the fragments is the most important risk factor for loss of fracture reduction. ${ }^{4}$ In completely displacement fractures, even after anatomical reduction, there is a high risk of loss of reduction, therefore percutaneous fixation with Kirschnner wires (K-wires) is recommended to maintain alignment. ${ }^{5}$

The ipsilateral fracture of the distal ulna metaphysis is also a risk factor for loss of reduction. ${ }^{6}$ Ozcan $\mathrm{M}$, et al cite the presence

All authors declare no potential conflict of interest related to this article.

The study was conducted at the Hospital do Instituto Dr. José Frota, Orthopedics and Traumatology Service, Fortaleza, Ceará, Brazil.

Correspondence: Jonatas Brito de Alencar Neto, Hospital do Instituto Dr. José Frota, 60025-061, Rua Barão do Rio Branco, 1816, Fortaleza, Ceará, Brazil. jonatasbrito19@hotmail.com 
of ulna fracture associated with a distal radius fracture as an indication of percutaneous fracture fixation with K-wires to prevent loss of reduction. ${ }^{5}$

Studies on the theme commonly do not differentiate the results of isolated fractures of the distal third of the radius from those that occur associated with fracture of the distal third of the ulna. ${ }^{1}$ Furthermore, fixation of the ulna when fixing the radius is also not a consensus in the literature.

This study aims to evaluate the clinical and radiological outcome of patients with fracture of the distal third of the forearm bones of children and adolescents when subjected to fixation with K-wires of both bones as the primary treatment. Secondarily, it seeks to identify the impact of the fixation of the two bones in the intraoperative period.

\section{METHODS}

A study carried out from June 12, 2019 to June 1, 2020, at a tertiary referral hospital in childhood traumatology.

This study included patients with an immature skeleton on radiography (that is, those whose growth plate is still open) and aged up to a maximum of 16 years, 11 months and 30 days, ${ }^{7}$ of both sexes, with fracture of the distal metaphyseal region of the forearm bones for surgical indication - considered when there is at least one fracture instability criterion, such as initial angle of fracture greater than 30 degrees, association with complete fracture or plastic deformity of theulna, initial displacement of fragments greater than $50 \%^{8}$ and were operated on at the Hospital of the study in the period from June 12, 2019 to June 1, 2020 by a single surgeon with expertise in child orthopedic trauma.

The study excluded patients who voluntarily did not return for post-operative consultations, those who had a fracture of only one forearm bone, those whose patients did not sign the Informed Consent Form or those legally responsible did not sign the Term Informed Consent Form.

A clinical, randomized, open and prospective study was carried out. The patients were divided into two groups: group A formed by the patients in which the radius and ulna were fixed and group $B$ formed by the patients in which only the radius was fixed. The sample size was defined based on the study by Ozcan et $\mathrm{al}^{5}$ being estimated at 40 patients in total to obtain statistical relevance.

During the study period, 16 patients were operated who met the inclusion and exclusion criteria, with six participants allocated to group A - fixed radius and ulna - and ten participants to group $\mathrm{B}$ - only the radius was fixed. All operated patients were followed up until the end of the study. (Figure 1)

Randomization was performed using Microsoft Excel ${ }^{\circledR}$ (Microsoft Corporation, Redmond, WA) to randomly select from a sample space of 40 numbers 20 participants in each group. The 40 numbers were then allocated in opaque envelopes to be opened only in the operating room to define which group the patient would belong to. All data obtained in the study were allocated in a spreadsheet using Microsoft Excel ${ }^{\circledR}$ (Microsoft Corporation, Redmond, WA).

After a patient of the study profile was admitted to the hospital, during hospitalization in the pediatric ward awaiting surgical treatment, he was invited to participate in the study by one of the researchers, and after consenting, preoperative information was filled in, which is identification, epidemiological and trauma-related data - mechanism, date and time - and fracture - deviation, percentage of contact between the fragments, angulation, shortening and presence of bone exposure. Until the surgical intervention was performed, the patient waited immobilized with an axillopalmar plastered splint.

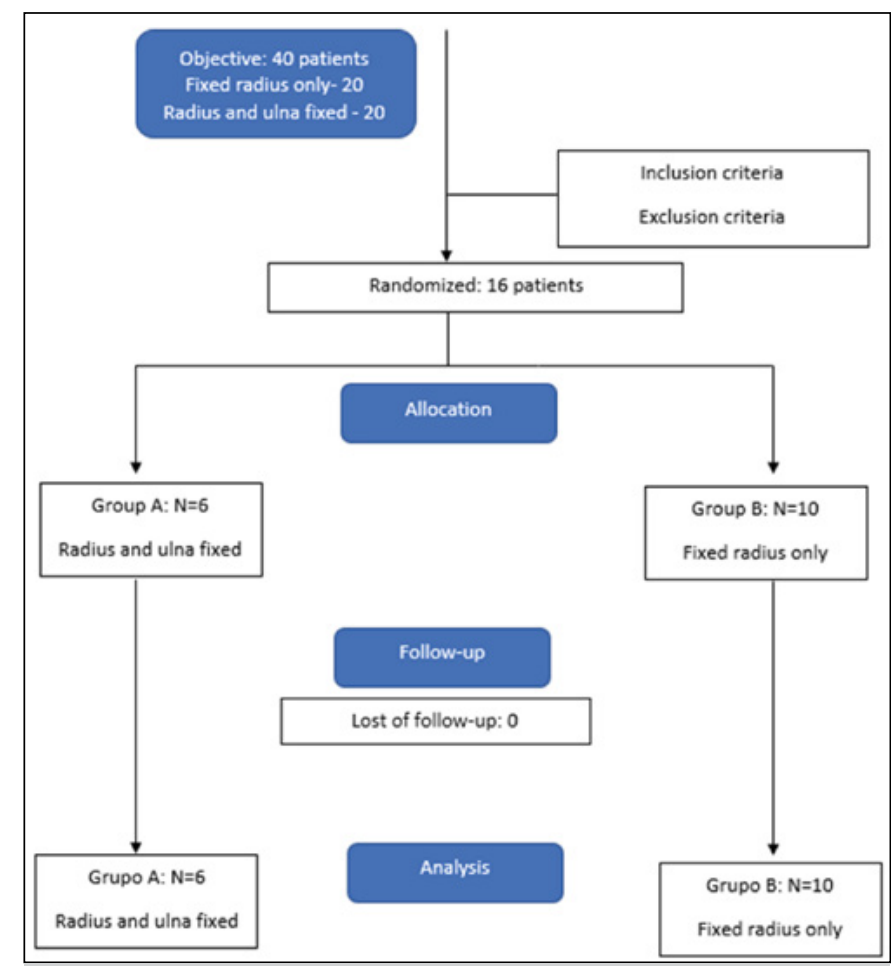

Figure 1. Patient enrollment as shown through a Consolidated Standards of Reporting Trials (CONSORT) 2010 flow diagram.

\section{Surgical technique}

The surgical procedure was performed with the patient in horizontal supine position under regional anesthesia using brachial plexus block via supraclavicular and axillary guided by - model GE Healthcare Venue ${ }^{\text {тм }} 40$ - and peripheral nerve stimulator Stimuplex ${ }^{\circledR}$ DIG RC (B. Braun, Melsung, Germany) and Levobupivacaine $0.2-0.25 \%$ associated with sedation with fentanyl 50 - 100mcg and midazolam 2-3mg(9). A single closed reduction attempt was made before degermation (retirar?), ${ }^{10}$ which was checked under fluoroscopy. When the fracture reduction was satisfactory, the radius was fixed percutaneously using two $1.5 \mathrm{~mm}$ kirschnner wires and a $1.5 \mathrm{~mm}$ kirschnner wire for ulnar fixation if it was assigned to the patient in question and immobilized with an axillopalmar plaster splint. The quality of the obtained reduction was classified as anatomical reduction (anatomical restoration), good ( $<10^{\circ}$ angulation or $<2 \mathrm{~mm}$ translation) and reasonable (10-20 angulation or translation $2-5 \mathrm{~mm}$ ).

Fluoroscopy was activated during surgery to check the reduction and fixation at the surgeon's discretion. The fluoroscopy equipment used is a Philips BV Pulsera CE 0344 (Koninklijke Philips Electronics N.V., Holland), which makes it possible to check how many times the fluoroscopy was activated and the time of radiation exposure information used in the study as well as the total surgical time. ${ }^{11}$ For this study, it was decided to adjust the device to $57 \mathrm{kV}$ and $1.5 \mathrm{~mA}$. After the procedure, the patient was followed up at the hospital's pediatric ward, receiving hospital discharge after 48 hours. All surgeries were performed by the same surgeon, who has expertise in child orthopedic trauma.

\section{Postoperative}

In order to assess pain in this study, the Visual Analogue Scale (VAS) was used, which consists of a score for measuring the intensity of pain by the patient shown on a straight line where at one end there is the marking "no pain" (0) advancing in towards the other end with indications of progressive increase in pain - mild 
pain (1 - 2), moderate pain (3 - 7), severe pain (8 - 9) - until the other end is marked "worst possible pain". ${ }^{10}$ VAS also has colors and images that help patients to define the intensity of pain. Patients were assessed for pain on the first and second postoperative days by one of the researchers and on each outpatient return by the surgeon. To assess the range of motion of the elbow and wrist in outpatient returns, a goniometer was used, with 0 - $145^{\circ}$ elbow flexion, 145 - $0^{\circ}$ elbow extension, Radioulnar pronation and supination of $0-90^{\circ}$, flexion were considered normal. $90^{\circ}$ wrist and 0 - $70^{\circ}$ wrist extension.

Functionality assessment was carried out by asking the patient and companion about the need for help with dressing, the need for help in bathing, the need for help with food, the need for help with personal hygiene when going to the bathroom and the absence of the ability to use the fractured limb to aid feeding. When the answer was "yes" to at least four of the questions, the patient was considered as "without difficulties", when it was "yes" to two or three questions was considered to have difficulty but did not need constant help and when the answer was "yes "to only one of the questions or none of them was considered to have difficulties and to need constant help to carry out the activities.

After discharge, the returns to the Traumatology Outpatient Clinic of the study hospital occurred at one, two, four, eight and twelve weeks after the operation, being evaluated on each return in addition to pain, the time of absence from school, the quality of the reduction presented, range of motion and presence of any complications.

\section{Statistical analysis}

In the statistical analysis, number of cases and percentages were used to describe the non-quantitative variables and mean and standard deviation (SD) or median (minimum - maximum) to describe quantitative variables. To verify normal distribution, the Shapiro-Wilk test was used, for comparisons between groups in relation to quantitative variables, the Student's t test was used for variables with normal distribution and the Mann-Whitney test for those who did not have this. distribution and Fisher's exact test for non-quantitative variables. The calculations were performed using $R$ Version 3.4.4 (2018-03-15). A 95\% confidence interval was considered.

The project was approved by the Research Ethics Committeein accordance with Resolution 466/2012 of the National Health Council (Guidelines and Regulatory Norms for Research Involving Humans) under registration 29142720.1.0000.5047. This study was funded by the researchers themselves.

\section{RESULTS}

Of the total participants, $14(87.5 \%)$ are male and 2 (12.5\%) female ( $p$ $=0.500)$ aged between six and 14 years $(p=0.476)$, with 8 years old most prevalent (31.25\%). As for laterality, $50 \%$ of patients fractured the right side and $50 \%$ the left side $(p=0.608)$, and when related to the patient's dominance, $56.25 \%{ }^{9}$ injured the dominant side and in $43.75 \%$ the injury was on the non-dominant side $(p=0.518)$. All fractures showed dorsal deviation, with $87.5 \%$ associated with radial displacement and $12.5 \%$ associated with ulnar deviation. (Table 1 ) The time elapsed between the accident and the attendance at the study institution it averaged 24.64 hours, ranging from 30 minutes to 102.5 hours, and the time between attendance and hospitalization until surgery was an average of 4.2 days, with a minimum of 1.5 hours and a maximum of 11 days.

Regarding the trauma mechanism, all referred to low-energy traumas described as falling to the ground (7), falling from a skateboard (1), falling from a horse (1), falling during a soccer game (1), falling from a ladder (1), drop of approximately 0.5 meters (1) and 1 meter (2) and drop of rede (2), which is a regional household appliance used for sleeping.
In the intraoperative period in group A, fluoroscopy was activated on average approximately 79 times (27-136) with an average radiation exposure time of 15.6 seconds (5.4 - 27.2 sec.) And the duration of surgery was from 15 to 47 minutes (average of 36 minutes). In group B, fluoroscopy was activated on average approximately 27 times (minimum 13 - maximum 46) $[p=0.011]$ with an average radiation exposure time of 5.2 seconds (2.6 - 9.2 seconds) and the duration of the surgery was 10 to 25 minutes (average of approximately 19 minutes) $[p=0.014]$. In the immediate postoperative period, anatomical reductions were obtained in 11 (68.8\%) patients, good in three (18.7\%) patients and reasonable in two (12.5\%) patients. (Table 2 )

In the postoperative period, group A classified pain according to the Visual Analogue Scale (VAS) on the first postoperative day on average $1.8(1-3)$ and on the second postoperative day approximately $67 \%$ did not complain of pain. In group B, the pain on the first postoperative day was an average of 4.7 VAS $(0-6)$ $[p=0.003]$ and on the second postoperative day, the mean was VAS $1.5(0-2)$ [ $p=0.009]$. (Table 3$)$

\begin{tabular}{|c|c|c|c|c|c|}
\hline & \multicolumn{2}{|c|}{$\begin{array}{c}\text { Radiusand ulna fixed } \\
(\mathrm{N}=6)\end{array}$} & \multicolumn{2}{|c|}{$\begin{array}{l}\text { Fixedradiusonly } \\
\qquad(\mathrm{N}=10)\end{array}$} & \multirow[b]{2}{*}{$p$} \\
\hline & Average/n & SD/\% & Average / $\mathbf{n}$ & $\mathrm{SD} / \%$ & \\
\hline Sex & & & & & $0,500^{2}$ \\
\hline Female & 0 & 0,0 & 2 & 100,0 & \\
\hline Male & 6 & 42,9 & 8 & 57,1 & \\
\hline Age (years) & 9,0 & 2,61 & 10,0 & 2,67 & 0,476 \\
\hline Laterality & & & & & $0,608^{2}$ \\
\hline Right & 4 & 50,0 & 4 & 50,0 & \\
\hline Left & 2 & 25,0 & 6 & 75,0 & \\
\hline Dominance & & & & & $0,518^{2}$ \\
\hline Right & 4 & 30,8 & 9 & 69,2 & \\
\hline Left & 2 & 66,7 & 1 & 33,3 & \\
\hline Exposedfracture & & & & & $0,125^{2}$ \\
\hline Yes & 2 & 100,0 & 0 & 0,0 & \\
\hline No & 4 & 28,6 & 10 & 71,4 & \\
\hline
\end{tabular}

(1-Test t de student; 2 - Test exato de Fisher).

Table 2. Intraoperative data.

\begin{tabular}{|c|c|c|c|c|c|}
\hline & \multicolumn{2}{|c|}{$\begin{array}{l}\text { Radiusand ulna fixed } \\
(\mathrm{N}=6)\end{array}$} & \multicolumn{2}{|c|}{$\begin{array}{l}\text { Fixedradiusonly } \\
\qquad(\mathrm{N}=10)\end{array}$} & \multirow[b]{2}{*}{$\mathbf{p}$} \\
\hline & $\begin{array}{c}\text { Average ou } \\
\text { Median }\end{array}$ & $\begin{array}{c}\text { SD } \\
\text { (Mín - Máx) }\end{array}$ & $\begin{array}{l}\text { Average } \\
\text { Median }\end{array}$ & \begin{tabular}{|c|} 
SD \\
(Mín - Máx) \\
\end{tabular} & \\
\hline $\begin{array}{l}\text { In-opfluoroscopy } \\
\text { (activations) }\end{array}$ & 78,7 & 45,3 & 26,6 & 11,5 & $0,011^{3}$ \\
\hline $\begin{array}{l}\text { Surgical time } \\
\text { in minutes }\end{array}$ & 36,8 & 11,8 & 19,3 & 4,4 & $0,014^{1}$ \\
\hline
\end{tabular}

(1 - Test t de student; 3 - Test de Mann-Whitney).

Table 3. Postoperative follow-up.

\begin{tabular}{c|c|c|c|c|c}
\hline & \multicolumn{2}{|c|}{$\begin{array}{c}\text { Radiusand ulna fixed } \\
(\mathbf{N}=\mathbf{6})\end{array}$} & \multicolumn{2}{c|}{$\begin{array}{c}\text { Fixedradiusonly } \\
\mathbf{( N = 1 0 )}\end{array}$} & \multirow{2}{*}{$\mathbf{p}$} \\
\cline { 2 - 5 } & Average & $\begin{array}{c}\text { SD } \\
\text { (Mín - Máx) }\end{array}$ & Average & $\begin{array}{c}\text { SD } \\
\text { (Mín - Máx) }\end{array}$ & \\
\hline VAS 10 PO & 2 & $(1-3)$ & 5 & $(0-6)$ & $0,003^{1}$ \\
\hline VAS 2 ${ }^{\circ}$ PO & 0 & $(0-1)$ & 2 & $(0-2)$ & $0,009^{3}$ \\
\hline VAS 1 week & 0 & $(0-0)$ & 2 & $(1-5)$ & $<0,001^{3}$ \\
\hline VAS 8 week & 0 & $(0-1)$ & 1 & $(0-2)$ & $0,114^{3}$ \\
\hline Schoolleave in days & 4 & $(3-4)$ & 10 & $(8-14)$ & $<0,001^{1}$ \\
\hline
\end{tabular}

(1 - Teste t de student 3 - Teste de Mann-Whitney); VAS - Visual Analogue Scale; PO - post operative. 
In the first reassessment 7 days after surgery, all patients in group A denied pain and had already returned to school activities. In group $B$, all of them complained of pain at some intensity, on average VAS $2(1-5)$ and no patient had returned to school activities. $(p<0.001)$

Radiologically, with 7 days postoperatively, in Group A, two patients presented radial deviation, one patient presented ulnar displacement and in none of the cases there was a shortening of the radius fracture. Regarding fracture of the ulna in Group A, one patient had a radial displacement and one patient progressed with a $1 \mathrm{~mm}$ shortening. In Group B, two patients had radial deviation, one patient had ulnar displacement and in none of the cases did the radius fracture shorten. Regarding fracture of the ulna in Group B, five patients had ulnar deviation, three patients had a shortening of two millimeters and one patient had a shortening of three millimeters. (Table 4)

In the reassessment performed 8 weeks after surgery, the radiological aspects were maintained in most patients, except for one patient in group B who presented slight loss of reduction, increasing the ulnar angulation of the radial fracture from $8^{\circ}$ to $10^{\circ}$. Upon examination of the range of motion, two patients in Group B presented alterations (one with loss of $5^{\circ}$ of supination of the wrist and one with loss of $5^{\circ}$ of wrist extension). No range of motion limitations were identified for patients in Group A. (Table 5) In relation to Activity of daily living with 8 weeks, in Group A one patient was classified as having no difficulties to perform basic activities of daily living, three had difficulty but did not need help and two had difficulty and needed help to carry out the activities. In Group B, two patients were classified as having no difficulties to perform basic activities of daily living, two had difficulties but did not need help and six had difficulty and needed help to perform the activities. There was no statistically significant difference in functionality.

On the outpatient return of 12 weeks postoperatively, no patient had range of motion restrictions or functional limitation. Total school leave in group A ranged from three to four days (mean 3.6

Table 4. Radiological aspects 1 week after surgery.

\begin{tabular}{|c|c|c|c|c|c|}
\hline $\mathrm{N}^{0}$ & $\begin{array}{c}\text { Ulna } \\
\text { fixation }\end{array}$ & $\begin{array}{c}\text { Radial Fracture, } \\
\text { angulation }\end{array}$ & $\begin{array}{c}\text { Radial Fracture, } \\
\text { Shortening } \\
\text { (mm) }\end{array}$ & $\begin{array}{c}\text { Ulnar Fracture, } \\
\text { angulation }\end{array}$ & $\begin{array}{c}\text { Ulnar Fracture } \\
\text { Shortening } \\
(\mathrm{mm})\end{array}$ \\
\hline 1 & Yes & - & - & - & - \\
\hline 2 & No & Radial $\left(12^{\circ}\right)$ & - & - & - \\
\hline 3 & No & Ulnar $\left(8^{\circ}\right)$ & - & $\begin{array}{l}\text { Ulnar }\left(26^{\circ}\right) / \\
\text { dorsal }\left(10^{\circ}\right)\end{array}$ & 3 \\
\hline 4 & No & Radial $\left(6^{\circ}\right)$ & - & - & - \\
\hline 5 & Yes & Radial $\left(4^{\circ}\right)$ & - & - & - \\
\hline 6 & No & - & - & $\begin{array}{l}\text { Ulnar }\left(13^{\circ}\right) / \\
\text { Dorsal }\left(4^{\circ}\right)\end{array}$ & 2 \\
\hline 7 & Yes & $\begin{array}{c}\text { Ulnar }\left(4^{\circ}\right) / \\
\text { Dorsal }\left(12^{\circ}\right)\end{array}$ & - & - & - \\
\hline 8 & No & - & - & Ulnar $\left(10^{\circ}\right)$ & - \\
\hline 9 & No & - & - & - & - \\
\hline 10 & No & - & - & - & - \\
\hline 11 & Yes & $\begin{array}{l}\text { Radial }\left(8^{\circ}\right) / \\
\text { Dorsal }\left(16^{\circ}\right) \\
\end{array}$ & - & $\begin{array}{c}\text { Radial }\left(10^{\circ}\right) / \\
\text { Dorsal }\left(8^{\circ}\right) \\
\end{array}$ & 1 \\
\hline 12 & No & - & - & $\begin{array}{l}\text { Ulnar }\left(4^{\circ}\right) / \\
\text { Volar }\left(12^{\circ}\right)\end{array}$ & 2 \\
\hline 13 & No & - & - & $\begin{array}{l}\text { Ulnar }\left(4^{\circ}\right) / \\
\text { Dorsal }\left(8^{\circ}\right)\end{array}$ & 2 \\
\hline 14 & No & - & - & - & - \\
\hline 15 & Yes & - & - & - & - \\
\hline 16 & Yes & - & - & - & - \\
\hline
\end{tabular}

days) and in group B it ranged from nine to 14 days (mean 10.4 days) [p <0.001]. (Table 6)

Regarding complications during the follow-up, three patients in group B had superficial K-wire infection, being treated with local measures, without using antibiotic therapy. Fracture healing was achieved in all patients ranging from six to nine weeks (three consolidated at six weeks, seven at seven weeks, four consolidated at eight weeks and two at nine weeks).

\begin{tabular}{|c|c|c|c|c|c|c|}
\hline $\mathbf{N}^{\circ}$ & $\begin{array}{c}\text { Ulna } \\
\text { fixation }\end{array}$ & $\begin{array}{c}\text { Radial } \\
\text { Fracture, } \\
\text { angulation }\end{array}$ & \begin{tabular}{|c|} 
Radial \\
Fracture, \\
Shortening \\
$(\mathrm{mm})$ \\
\end{tabular} & $\begin{array}{c}\text { Ulnar } \\
\text { Fracture, } \\
\text { angulation }\end{array}$ & \begin{tabular}{|c|} 
Ulnar \\
Fracture, \\
Shortening \\
$(\mathrm{mm})$ \\
\end{tabular} & complications \\
\hline 1 & Yes & - & - & - & - & - \\
\hline 2 & No & Radial $\left(12^{\circ}\right)$ & - & - & - & Superficial infection \\
\hline 3 & No & Ulnar $\left(10^{\circ}\right)$ & - & \begin{tabular}{|l|} 
Ulnar $\left(26^{\circ}\right)$ \\
Dorsal $\left(10^{\circ}\right)$ \\
\end{tabular} & 3 & Slightreductionloss \\
\hline 4 & No & - & - & - & - & - \\
\hline 5 & Yes & Radial $\left(4^{\circ}\right)$ & - & - & - & - \\
\hline 6 & No & & - & \begin{tabular}{|l|} 
Ulnar $\left(13^{\circ}\right)$ \\
Dorsal $\left(4^{\circ}\right)$ \\
\end{tabular} & 2 & Superficial infection \\
\hline 7 & Yes & $\begin{array}{c}\text { Ulnar }\left(4^{\circ}\right) \\
\text { Dorsal }\left(12^{\circ}\right)\end{array}$ & - & - & - & - \\
\hline 8 & No & - & - & Ulnar $\left(10^{\circ}\right)$ & - & - \\
\hline 9 & No & - & - & - & - & - \\
\hline 10 & No & - & - & - & - & - \\
\hline 11 & Yes & \begin{tabular}{|l|} 
Radial $\left(8^{\circ}\right) /$ \\
Dorsal $\left(16^{\circ}\right)$ \\
\end{tabular} & - & \begin{tabular}{|l|} 
Radial $\left(10^{\circ}\right)$ \\
Dorsal $\left(8^{\circ}\right)$ \\
\end{tabular} & 1 & - \\
\hline 12 & No & - & - & \begin{tabular}{|c|} 
Ulnar $\left(4^{\circ}\right)$ \\
$\operatorname{Volar}\left(12^{\circ}\right)$
\end{tabular} & 2 & - \\
\hline 13 & No & - & - & $\begin{array}{c}\text { Ulnar }\left(4^{\circ}\right) \\
\text { Dorsal }\left(8^{\circ}\right) \\
\end{array}$ & 2 & - \\
\hline 14 & No & - & - & - & - & - \\
\hline 15 & Yes & - & - & - & - & - \\
\hline 16 & Yes & - & - & - & - & - \\
\hline
\end{tabular}

Table 6. Clinical and Functional Evaluation 8 weeks after surgery.

\begin{tabular}{|c|c|c|c|c|}
\hline & & $\begin{array}{c}\text { Grupo A: } \\
\text { Radiusand } \\
\text { ulna fixed } \\
\quad N=6\end{array}$ & $\begin{array}{c}\text { Grupo B: } \\
\text { Fixedradiusonly } \\
\mathrm{N}=10\end{array}$ & $p$ \\
\hline \multirow{3}{*}{$\begin{array}{l}\text { Independence for } \\
\text { basic activities } \\
\text { of daily living }\end{array}$} & No difficulty & 1 & 2 & \multirow{3}{*}{$0,165^{2}$} \\
\hline & $\begin{array}{c}\text { Difficulty, but no } \\
\text { help needed }\end{array}$ & 3 & 2 & \\
\hline & $\begin{array}{l}\text { Difficulty and } \\
\text { need help }\end{array}$ & 2 & 6 & \\
\hline \multirow{3}{*}{$\begin{array}{l}\text { Arcof motion } \\
\text { limitation }\end{array}$} & Elbow & - & - & \\
\hline & \begin{tabular}{|c|}
$\begin{array}{c}\text { Wrist (flexion } \\
\text { and extension) }\end{array}$ \\
\end{tabular} & - & $\begin{array}{l}\text { lossof } 5^{\circ} \\
\text { extension (1) }\end{array}$ & \\
\hline & $\begin{array}{l}\text { Wrist (prone- } \\
\text { supination) }\end{array}$ & - & $\begin{array}{c}\text { lossof } 5^{\circ} \\
\text { supination (1) }\end{array}$ & \\
\hline
\end{tabular}

(2 - Test exato de Fisher).

\section{DISCUSSION}

Fractures of the distal third of the radius correspond to 20 - 35\% of all childhood fractures and $80 \%$ of pediatric fractures that occur in the forearm. ${ }^{12}$ The indirect costs of this injury are incalculable in terms of medical costs, absent period in school activities and future potential working. ${ }^{1}$

Loss of reduction is the most common complication of conservative treatment, so that more than a third of patients will progress with 
this complication ${ }^{13}$.Associated ulna fracture is cited in several studies as a risk factor for loss of reduction, ${ }^{4,5,14}$ configuring as a relative indication of fracture fixation with Kirschnner wires, ${ }^{6}$ but indications regarding fixing the ulna together with fixing the radius are not well defined and what is the impact of this additional fixation for the patient. Percutaneous fixation with Kirschnner wires is generally preferred when distal radius fractures in the pediatric population require surgical stabilization. ${ }^{15}$ There are variations in the fixation configuration, with several techniques described. The wires can be introduced proximal to the physis in order to cross each other to provide stability, ${ }^{16,17}$ the wires can be pre-concealed for arching in the internal cortex ${ }^{15}$ transepiphyseal ${ }^{18}$ in the case of slightly more proximal fractures. Kapandji's technique ${ }^{19}$ is also widely used in metaphyseal fractures with the need for greater attention to veins, tendons and nerves at risk in this approach. ${ }^{18}$ When the ulna is fixed, it is performed using a cross-wire technique ${ }^{16}$, intramedullary by anterograde approach ${ }^{18}$ or retrograde.

Most complications occur due to inadequate indication or poorly performed surgical technique. ${ }^{20}$ In this study, the Kapandji technique was used to fix the radius in all patients and the ulna fixation was performed by retrograde or anterograde intramedullary route, with no inherent complications identified surgical technique.

Factors associated with loss of reduction are considered to be low technical quality in the making of plastered immobilization, associated fracture of the ulna, and initial angular greater than $30^{\circ} .{ }^{12}$ Other associated factors are age greater than 10 years, bayonet fracture, fracture line oblique and failure to achieve anatomical reduction in primary treatment. ${ }^{21}$ Initial angular greater than $30^{\circ}$ and initial translation greater than $50 \%$ are described as relative indication of fixation with $\mathrm{K}$ wires. ${ }^{12}$

Ozcan et al retrospectively evaluated 40 children with distal radius fracture, dividing them into two groups, one with conservative treatment and the other with fixation with $\mathrm{K}$ wires, with loss of reduction being observed in $10 \%$ of patients with fixation with wires and in $50 \%$ of patients with only closed reduction. ${ }^{5}$ Satish et al treated 52 children with distal radius fractures using the Kapandji technique, with no cases of loss of reduction being identified in any of the patients. ${ }^{21}$ Parikh et al in a retrospective case-control study compared the evolution of 10 children treated with the kapandji technique with 26 treated with cross-wire fixation and concluded that the Kapandji technique was superior in maintaining the reduction. ${ }^{22}$ In this study, the loss of reduction occurred in only one patient, who had no indication for a new intervention because the reduction remained within acceptable criteria, confirming previous studies where the Kapandji technique was effective in maintaining the reduction of the fracture. and corroborating the systematic review carried out by Khandekar, Tolessa and Jones who concluded that fixation with $\mathrm{k}$ wires implies a minimal incidence of loss of reduction. ${ }^{17}$ Ozcan et al performed a functional assessment of 40 patients in their study only at the end of the follow-up, which was 20 months, finding no differences between groups. ${ }^{5}$ Biju, likewise, prospectively evaluated 31 patients treated conservatively or with percutaneous fixation, finding no functional difference at the end of the 24-week follow-up. ${ }^{23}$

No long-term functional difference was found by Syurahbil et al when retrospectively evaluating 57 patients treated with percutaneous or conservative fixation. ${ }^{24}$ The results of this study corroborate with the literature because at the end of the follow-up, no patient had functional limitation, however the group whose ulna was also fixed evolved faster for functional recovery, returning first to school activities, and obtained lower scores in relation to pain in the post operative.

Mclauchlan et al identified that the amount of radiographs taken in conservative treatment - due to the need for more frequent returns and radiographs at each reevaluation - is greater than with the fixation by $\mathrm{K}$ wire. ${ }^{25} \mathrm{Jin}$ et al compared intraoperative fixation of distal radius fractures with wires associated or not with ulna fixation, presenting a longer surgical time and exposure to fluoroscopy in those whose ulna fixation was performed. ${ }^{16}$ The results obtained in this study corroborate with Jin et al because longer surgical time and fluoroscopic activations were found in patients whose ulna was fixed.

The limitations of this study are found in the small number of cases evaluated, follow-up times of less than 12 months and lack of standardization regarding the time elapsed between the fracture and surgical treatment. However, it was possible to observe statistical relevance in the results and in the last evaluation there were no functional or consolidation differences between the groups. In addition, no fractures with signs of advanced consolidation were treated and there were no statistical differences regarding the quality of the reduction between the groups, regardless of the fracture time.

Further studies are needed to assess fractures of the distal third of the radius when they are associated with ipsilateral fracture of the ulna with an emphasis on the impact of ulna fixation on the patient's functional and radiological evolution. Randomized clinical studies with a larger number of patients will be important to define more clearly the best treatment for these patients.

\section{CONCLUSION}

From this study it can be concluded that patients with distal radius fracture associated with ipsilateral fracture of the distal ulna have faster functional recovery and less postoperative pain when the ulna is also fixed with $\mathrm{K}$ wires. However, the surgical time and the amount of intraoperative fluoroscopic activations increases when compared to isolated radius fixation.

The functional and radiological result at the end of the treatment proved to be the same regardless of the fixation of the ulna. In addition, the Kapandji technique was efficient in maintaining the reduction after fixation of the radius.

AUTHORS' CONTRIBUTION: Each author contributed individually and significantly to the development of this article. JBAN: creator and mentor of the article. APS, GVAB, LHPN: data collect. MLCC: statistical analysis.

\section{REFERENCES}

1. Nellans KW, Kowalski E, Chung KC. The Epidemiology of Distal Radius Fractures. Hand Clin. 2012;28(2):113-25.

2. Chia B, Kozin SH, Herman MJ, Safier S, Abzug JM. Complications of pediatric distal radius and forearm fractures. In: Instructional course lectures. 2015. p. 499-507.

3. Miller BS, Taylor B, Widmann RF, Bae DS, Snyder BD, Waters PM. Cast immobilization versus percutaneous pin fixation of displaced distal radius fractures in children: A prospective, randomized study. J Pediatr Orthop. 2005;25(4):490-4.
4. Zamzam MM, Khoshhal $\mathrm{KI}$. Displaced fracture of the distal radius in children. J Bone Jt Surg - Ser B. 2005;87(6):841-3.

5. Ozcan M, Memisoglu S, Copuroglu C, Saridogan K. Percutaneous Kirschner wire fixation in distal radius metaphyseal fractures in children: Does it change the overall outcome? Hippokratia. 2010;14(4):265-70.

6. Hang JR, Hutchinson AF, Hau RC. Risk factors associated with loss of position after closed reduction of distal radial fractures in children. J Pediatr Orthop. 2011;31(5):501-6. 
7. Herring JA. Tachdjian's Pediatric Orthopaedics: From the Texas Scottish Rite Hospital for Children [Internet]. Accessed on: June 20th, 2019. $5^{\circ}$ ed. Elsevier Saunders; 2014. (ClinicalKey 2012). Available at: https://books.google.com.br/ books?id=N42oxQEACAAJ

8. McQuinn AG, Jaarsma RL. Risk factors for redisplacement of pediatric distal forearm and distal radius fractures. J Pediatr Orthop. 2012;32(7):687-92.

9. Takeda A, Ferraro LHC, Rezende AH, Sadatsune EJ, Falcão LF dos R, Tardelli MA. Minimum effective concentration of bupivacaine for axillary brachial plexus block guided by ultrasound. Brazilian J Anesthesiol (English Ed [Internet]). Accessed on: July 12th, 2019. 2015;65(3):163-9. Available at: http://dx.doi. org/10.1016/j.bjane.2013.11.007

10. Caruso G, Caldari E, Sturla FD, Caldaria A, Re DL, Pagetti P, et al. Management of pediatric forearm fractures: what is the best therapeutic choice? A narrative review of the literature. Musculoskelet Surg. 2020;(0123456789).

11. Kalenderer Ö, Turgut A, Bilgin E, Erkus S, ípci FB, Edizsoy TP. The Influence of Resident Level of Training on Fluoroscopy Time in Pediatric Supracondylar Humeral Fractures Treated with Closed Reduction and Percutaneous Pinning. Cureus. 2018;10(2):2-7.

12. Stutz C, Mencio GA. Fractures of the distal radius and ulna. J Pediatr Orthop. 2010;30(2):85-9.

13. Bae DS. Pediatric Distal Radius and Forearm Fractures. J Hand Surg Am [Internet]. Accessed on: August, 4th, 2019. 2008;33(10):1911-23. Available at: http://dx.doi.org/10.1016/j.jhsa.2008.10.013

14. Bohm ER, Bubbar V, Hing KY, Dzus A. Above and below-the-elbow plaster casts for distal forearm fractures in children: A randomized controlled trial. J Bone Jt Surg - Ser A. 2006;88(1):1-8

15. Varga M, Józsa G, Fadgyas B, Kassai T, Renner A. Short, double elastic nailing of severely displaced distal pediatric radial fractures. Med (United States). 2017;96(14):1-5.
16. Li J, Rai S, Tang X, Ze R, Liu R, Hong P. Fixation of delayed distal radial fracture involving metaphyseal diaphyseal junction in adolescents: A comparative study of crossed Kirschner-wiring and non-bridging external fixator. BMC Musculoskelet Disord. 2020;21(1):1-8.

17. Khandekar S, Tolessa E, Jones S. Displaced distal end radius fractures in children treated with Kirschner wires -A systematic review. Acta Orthop Belg. 2016;82(4):681-9.

18. Lieber J, Schmid E, Schmittenbecher PP. Unstable diametaphyseal forearm fractures: Transepiphyseal intramedullary Kirschner-wire fixation as a treatment option in children. Eur J Pediatr Surg. 2010;20(6):395-8.

19. Hoel G, Kapandji Al. Ostdosynthbse par broches intra-focales des fractures ddplacement ant6rieur de 1 ' 6 piphyse radiale infdrieure. Ann Chir la Main. 1995;14(5):142-57.

20. Bukvić N, Marinović M, Bakota B, Veršić AB, Karlo R, Kvesić A, et al. Complications of ESIN osteosynthesis-Experience in 270 patients. Injury. 2015;46:S40-3.

21. Satish BRJ, Vinodkumar M, Suresh M, Seetharam PY, Jaikumar K. Closed reduction and K-wiring with the Kapandji technique for completely displaced pediatric distal radial fractures. Orthopedics. 2014;37(9):e810-6.

22. Parikh SN, Jain V V., Youngquist J. Intrafocal pinning for distal radius metaphyseal fractures in children. Orthopedics. 2013;36(6):783-8.

23. Biju Jayaprakash Shetty. A Prospective comparative study of closed reduction and above elbow cast versus closed reduction and percutaneous K-wire fixation in completely displaced distal radius metaphyseal fractures in children. Rajiv Gandhi University Of Health Sciences; 2011.

24. Syurahbil AH, Munajat I, Mohd EF, Hadizie D, Salim AA. Displaced physeal and metaphyseal fractures of distal radius in children. Can wire fixation achieve better outcome at skeletal maturity than cast alone? Malaysian Orthop J. 2020;14(2):1-11.

25. McLauchlan GJ, Cowan B, Annan IH, Robb JE. Management of completely displaced metaphyseal fractures of the distal radius in children. A prospective, randomised controlled trial. J Bone Jt Surg - Ser B. 2002;84(3):413-7. 